\title{
WEGGIERSKIE POIMKI A POLSKIE PRZYIMKI WTÓRNE - UJĘCIE PORÓWNAWCZE W ASPEKCIE (GLOTTO)DYDAKTYCZNYM
}

Słowa kluczowe: poimek, przyimek wtórny, język polski, język węgierski

Streszczenie. Język węgierski jest językiem bezprzyimkowym. W polszczyźnie natomiast można wyodrębnić dwie grupy przyimków - pierwotne i wtórne. Odpowiednikiem węgierskim polskich przyimków pierwotnych jest syntetyczna forma kazualna, np.: Łódźban 'w Lodzi', natomiast ekwiwalentem przyimków wtórnych są poimki (postpozycje), np.: az apámnak köszönhetöen 'dzięki mojemu ojcu', az egyetemmel szemben 'naprzeciwko uniwersytetu'. W języku węgierskim wyodrębnia się trzy grupy poimków: łączące się z nominativem, np. a professzor szerint 'według profesora', łączące się z przypadkami zależnymi, np. az úton keresztül 'przez drogę', zawierające afiks dzierżawczy, np. az anyám ellenére 'na przekór mojej matce'. Zrozumienie obu systemów i ich praktyczne opanowanie jest poważnym wyzwaniem dla uczących (się). Mimo odrębności genetycznych i typologicznych istnieje bardzo wysoki stopień ekwiwalencji w strukturach obu języków, obejmującej zarówno warstwę leksykalną, jak i gramatyczną.

Niniejsze rozważania są kontynuacją dociekań nad istotą polskich przyimków w aspekcie porównawczym polsko-węgierskim (Stefańczyk 2018).

Węgierszczyzna jest językiem aglutynacyjnym typu postpozycyjnego. Oznacza to, że wszystkie morfemy są dołączane (doklejane) w postpozycji względem rdzenia wyrazu, np.: Európá-ban 'w Europie', autó-i-m-ban 'w moich samochodach', villamos-ra 'na tramwaj'. Aglutynacja może być także realizowana prepozycyjnie względem rdzenia wyrazu, co ma miejsce w wielu językach Afryki, por. suahili kanisa 'kościół', kwa-kanisa 'w kościele' (Stopa, Garlicki 1966; Polański 1993). Wszystkie morfemy dołączane do rdzenia wyrazu są w języku węgierskim zasadniczo jednofunkcyjne, np. w formie autókban rdzeniem jest autó 'samochód, auto’, - $k$ - jest wykładnikiem liczby mnogiej, natomiast -ban jest wskaźnikiem przypadka (inessivus). Dzięki istnieniu odrębnego wykładnika liczby $(-k-)$

*reinhold5@interia.pl, Uniwersytet Jagielloński, Wydział Polonistyki, Centrum Języka i Kultury Polskiej w Świecie, ul. Grodzka 64, 30-004 Kraków. 
ta sama końcówka występuje w obu liczbach, por. autóban 'w samochodzie', autókban 'w samochodach'. We fleksyjnej polszczyźnie natomiast morfem fleksyjny kumuluje w sobie kilka funkcji, np. w formie synowi końcówka -owi wskazuje jednocześnie na przypadek, liczbę i rodzaj. W przeciwieństwie do języka węgierskiego w obu liczbach występują zasadniczo - poza formami synkretycznymi - różne końcówki - inne w liczbie pojedynczej i inne w liczbie mnogiej, o czym decydują czynniki typologiczne (por. synowi-synom).

Znamienną cechą języków aglutynacyjnych, w tym także węgierszczyzny, jest brak prepozycji. Ekwiwalentem polskich przyimków, zwłaszcza pierwotnych, jest w węgierszczyźnie syntetyczny przypadek, por. parkban 'w parku' (inessivus), parkból 'z parku' (elativus), parkba 'do parku' (illativus), ebéden 'na obiedzie' (supressivus), ebédröl 'z obiadu' (delativus), ebédre 'na obiad' (sublativus), az apámnál 'u mojego ojca' (adessivus), az apámtól 'od mojego ojca' (ablativus), az apámhoz 'do mojego ojca' (allativus). Tu należy podkreślić, że węgierszczyzna jest językiem o silnie rozbudowanym systemie przypadkowym. W zależności od ujęcia liczba przypadków waha się od 20 (Balogh 2000, s. 183-208) do 25 (Csapláros 1963).

Same jednak końcówki - mimo ich bogactwa - nie były w stanie precyzyjnie wyrażać różnego rodzaju relacji, np. przestrzennych czy czasowych. W związku z tym w ciągu dziejów języka pojawiały się dodatkowe elementy, doprecyzowujące informacje zawarte w afiksie kazualnym. Są to tzw. poimki (węg. névutó), występujące konsekwentnie w postpozycji względem form kazualnych.

W językoznawstwie hungarystycznym wyodrębnia się trzy grupy poimków:

1. łączące się z nominativem;

2. łączące się z przypadkami zależnymi;

3. zawierające morfem dzierżawczy (Balogh 2000, s. 261-265).

Grupę pierwszą oprócz poimków fölött 'nad', alatt 'pod', elött 'przed', mögött 'za', között 'między' i ich wariantów (Stefańczyk 2018) reprezentują liczne postpozycje typu:

által 'przez', np. az ember által 'przez człowieka' (dosłownie czlowiek przez), úlva 'za', np. egy óra múlva 'za godzinę',

óta 'od', np. két év óta 'od dwóch lat', szerint 'według', np. az anyám szerint 'według mojej matki', helyett 'zamiast', np. tea kávé helyett 'herbata zamiast kawy', körül 'wokół', np. az asztal körül 'wokół stołu', nélkül 'bez', np. cukor nélkül 'bez cukru', miatt 'z powodu', np. a betegség miatt 'z powodu choroby', mellett 'obok', np. az ablak mellet 'obok okna'.

Znaczna część tego typu poimków może przybierać morfemy dzierżawcze, co jest obce językowi polskiemu, np.: 
mellettem 'obok mnie' mellettünk 'obok nas'

melletted 'obok ciebie' mellettetek 'obok was'

mellette 'obok niego, niej' mellettük 'obok nich'.

Wiąże się to z faktem, że w języku węgierskim w zasadzie nie ma zaimków dzierżawczych. Ich funkcje pełnią morfemy - $m,-d,-e,-u ̈ n k$, -tek -ük dodawane do rdzenia wyrazu zespolone z nim odpowiednią samogłoską łączącą zgodnie z zasadą harmonii wokalicznej. Zaimki dzierżawcze w języku węgierskim występują wyłącznie w funkcji orzecznika, np. Ez a könyv enyém 'Ta książka jest moja' (por. ang. mine) i podmiotu, np. Az enyém sem jó 'Mój (moja, moje) też nie jest dobry (dobra, dobre)'.

Grupa druga uwzględnia poimki łączące się z przypadkami zależnymi. Oto wybrane przykłady:

supressivus:

-n kívül 'oprócz, poza, na zewnątrz', np.: ezen kívül 'oprócz tego, poza tym', a városon kvül 'poza miastem',

-n túl 'za', np. a hegyeken túl 'za górami',

-n keresztül 'przez', np. Budapesten keresztül 'przez Budapeszt',

-n át 'przez', np. Krakkón át 'przez Kraków.

Polskim odpowiednikiem węgierskiego supressivu jest na ogół konstrukcja $n a+$ miejscownik, por. az asztalon 'na stole'. W wypadku poimków są to jednak różne konstrukcje przyimkowo-rzeczownikowe.

allativus:

-hez képest 'w porównaniu z', np. Budapest Krakkóhoz képest nagyobb 'Budapeszt w porównaniu z Krakowem jest większy'.

Polskim ekwiwalentem węgierskiego allativu jest konstrukcja do + dopełniacz. dativus:

-nek köszönhetöen 'dzięki’, np. a szüleimnek köszönhetően ‘dzięki moim rodzicom’; instrumentalis comitativus:

-vel szemben 'naprzeciw, naprzeciwko', np. iskolával szemben 'naprzeciwko szkoły'.

W językoznawstwie hungarystycznym - zarówno w ujęciach tradycyjnych, jak i nowszych (Velcsov 1991; Balogh 2000) - jako poimki traktuje się zleksykalizowane formy imiesłowowe typu fogva, kezdve, nézve, łączące się z przypadkami zależnymi, np.:

ablativus:

-tól fogva 'począwszy od', np. holnaptól fogva 'począwszy od jutra';

adessivus:

-nál fogva 'z powodu, ze względu', np.: ennél fogva 'z tego powodu', sublativus:

-ra nézve 'biorąc pod uwagę', np. a munkájára nézve 'biorąc pod uwagę jego/jej pracę'. 
Grupę trzecią - jak wspomniano - reprezentują poimki zawierające morfem dzierżawczy. Postpozycje te ze względu na swą specyfikę wymagają odrębnego komentarza. Otóż w języku węgierskim konstrukcje dzierżawcze wyraża się za pomocą morfemów: $-a-,-e-,-j a-,-j e-\mathrm{w}$ liczbie pojedynczej oraz $-i-,-a i-$, $-e i,-j a i-,-j e i-\mathrm{w}$ liczbie mnogiej. Dobór odpowiedniego morfemu związany jest z jakością wygłosu oraz harmonią wokaliczną. W przeciwieństwie jednak do języków indoeuropejskich, a także ugrofińskich jak fiński czy estoński (Wojan 2016; Elert 1995) morfem dzierżawczy otrzymuje nie posiadacz, lecz przedmiot posiadany, $\mathrm{np}$.:

professzor példánya 'egzemplarz profesora' (dosłownie: profesor egzemplarz jego)

a folyóirat szerkesztösége 'redakcja czasopisma'

Beáta autója 'samochód, auto Beaty'

Anna barátja 'przyjaciel Anny'

az elnök autói 'samochody prezesa'

a lányom barátai 'przyjaciele mojej córki'

a tanár könyvei 'książki nauczyciela'

szeptember utolsó napjai 'ostatnie dni września'

az egyetem kertjei 'ogrody uniwersytetu'.

Odpowiednikiem polskim tego typu struktur są syntetyczne konstrukcje dopełniaczowe, w których - podobnie jak w innych językach indoeuropejskich - końcówkę bądź inny wykładnik dzierżawczy otrzymuje przedmiot posiadany.

Do morfemów dzierżawczych w ostatniej kolejności dołączane są wykładniki przypadka, będące odpowiednikiem polskich końcówek fleksyjnych i przyimków pierwotnych, np.:

Beáta barátaihoz megyek 'Idę do przyjaciół Beaty'

Nowak lányával találkoztam 'spotkałem się z córką Nowaka'.

Tego typu skostniałe struktury, zawierające afiks dzierżawczy oraz końcówkę przypadka zależnego, stały się podstawą poimków, por. eset 'przypadek, wypadek', esete 'jego, jej przypadek, wypadek', esetében 'w przypadku, w wypadku'. Po dodaniu morfemu kazualnego poprzedzająca go samogłoska ulega wzdłużeniu (tu e:é). Omawiana grupa postpozycji wymaga użycia form mianownikowych. Oto wybrane przykłady:

alapján 'na podstawie' (alap 'podstawa'), np. a szerződés alapján 'na podstawie umowy' (dosłownie: umowa - podstawa jej na),

alkalmából 'z okazji' (alkalom 'okazja, sposobność'), np. a születésnapja alkalmából 'z okazji jej//jego urodzin',

céljából 'w celu' (cél 'cel'), np. szórakozás céljából 'w celu rozrywki, dla rozrywki', dacára 'na przekór' (dac 'przekora'), np. a nehézségek dacára 'na przekór trudnościom',

ellenére 'mimo, pomimo, przeciw, przeciwko' (ellen 'przeciw'), np. mindennek ellenére 'mimo wszystko', feminizmus ellénere 'przeciwko feminizmowi', 
értelmében 'w myśl' (értelem 'umysł, rozum, sens', np. a szerzödés értelmében 'w myśl umowy', esetében 'w wypadku, w przypadku' (eset 'wypadek, przypadek', np. halál esetében 'w wypadku śmierci',

folyamán 'w ciągu, w toku, w trakcie' (folyam 'rzeka'), np. a beszélgetés folyamán 'w ciągu, w trakcie rozmowy',

javára 'dla dobra, na korzyść, na rzecz’ (java 'dobro, korzyść'), np. az ország javára 'dla dobra kraju',

keretében 'w ramach' (keret 'rama'), np. a szerzödés keretében 'w ramach umowy', következtében 'w następstwie, wskutek, w wyniku, w konsekwencji' (következet 'następstwo, skutek'), np. a baleset következtében 'w wyniku wypadku',

közben 'w czasie' (köz 'odstęp czasu, interwał'), np. az elöadás közben 'w czasie wykładu',

nevében 'w imieniu' (név 'imię'), np. a föorvos nevében 'w imieniu ordynatora', nyomán 'na podstawie, według' (nyom 'ślad'), np. a vizsgálat nyomán 'na podstawie badań,

számára 'dla' (szám 'liczba, numer'), np. Nowak úr számára 'dla pana Nowaka), részére 'dla' (rész 'część'), np. az igazgató részére 'dla dyrektora'.

Z punktu widzenia osób polskojęzycznych uczących się języka węgierskiego największy stopień trudności - jak się wydaje - cechuje grupę drugą. Wymaga ona bowiem zarówno znajomości konkretnego poimka, jak i (zwłaszcza) odpowiedniego przypadka. Niezwykle przydatna okazuje się tu także znajomość etymologii poimka. Jest ona niejednokrotnie kluczem do wyboru odpowiedniej formy kazualnej, por. szemben 'naprzeciwko' (dosłownie 'w oku'), np. a szoborral szemben 'naprzeciwko pomnika' (dosłownie 'z pomnikiem w oku'). W wypadku grupy drugiej i trzeciej pewnego rodzaju trudnością mogą być morfemy dzierżawcze, które fakultatywnie bądź obowiązkowo są dodawane do rdzenia wyrazu. Konstrukcje niezawierające morfemu dzierżawczego są stosunkowo proste, np.: a professzor szerint 'według profesora', halál esetén 'w wypadku jego/jej śmierci', natomiast konstrukcje zawierające obcy polszczyźnie morfem dzierżawczy wymagają gruntownej znajomości morfologii węgierskiej, np.: a professzorunk szerint 'według naszego profesora', halála esetén 'w wypadku jej//jego śmierci'.

Przyimki wtórne stanowią najmłodszą warstwę polskich postpozycji. W języku staropolskim była to grupa bardzo nieliczna (Krążyńska 2015). Istotny ich wzrost nastąpił w XVIII stuleciu, co się wiązało - jak dowodzą badania - z ogólnoeuropejskim procesem zmierzającym do osłabienia bądź całkowitego zaniku fleksji (Bajerowa 1964). W ostatnich dziesięcioleciach obserwuje się znaczący wzrost przyimków wtórnych (Przybylska 2002, Milewska 2003).

Polskie przyimki wtórne - podobnie jak poimki węgierskie - tworzą zbiór otwarty, ciągle bowiem powstają nowe tego typu leksemy, w związku z czym trudno jest jednoznacznie określić ich ilość. Z etymologicznego punktu widzenia są to niejednokrotnie skostniałe formy kazualne, np.: środkiem, względem, skutkiem, 
w tym także struktury dwu- lub trzywyrazowe, np.: w czasie, $w$ obliczu, z powo$d u, w$ imieniu, $w$ ramach, $w$ celu, pod pozorem, $w$ zamian $z a$, bez względu na. W przeciwieństwie do przyimków pierwotnych łączą się one tylko z jednym przypadkiem. Jako przykład może posłużyć przyimek pierwotny $z(e)$, który się łączy z dopełniaczem, np. $z$ Łodzi, biernikiem, np. poproszę z dziesięć plasterków szynki i narzędnikiem, np. herbata z cytryną. Przyimki pierwotne - w przeciwieństwie do wtórnych - mogą mieć kilka ekwiwalentów w językach obcych. Na przykład przyimek do ma trzy ekwiwalenty w języku węgierskim, np.: Krakkóba 'do Krakowa' (illativus), szombatig 'do soboty' (terminativus), Annához 'do Anny' (allativus).

Część omawianych struktur może być jednocześnie przyimkiem i przysłówkiem, np. Nasz dom jest obok parku. Mieszkamy tuż obok. Tego typu przykłady występują także w języku węgierskim, np. kívül 'na zewnątrz, poza' (Keszler 2000).

Najwięcej przyimków wtórnych łączy się we współczesnej polszczyźnie $\mathrm{z}$ dopełniaczem. Nie powinno to dziwić, genetivus bowiem jest przypadkiem o najwyższej frekwencji (Miodunka 1992, Tokarski 2001). Ilustrują to zamieszczone poniżej wybrane przykłady: blisko, dookoła, koło, mimo, na domiar, na mocy, naokoło, na podstawie, na rzecz, na skutek, na tle, na wprost, na zasadzie, obok, odnośnie do, około, opodal, podczas, pod pozorem, pod wplywem, pod względem, skutkiem, $w$ celu, $w$ charakterze, $w$ ciagu, $w$ czasie, $w$ dziedzinie, wedtug, w imieniu, w miare, w myśl, wobec, w obliczu, w obrębie, wokót, wokoto, $w$ poblizu, $w$ poprzek, $w$ ramach, $w$ razie, wskutek, $w$ stosunku do, $w$ trakcie, $w$ wyniku, w zakresie, wzdhuz, względem, zamiast, za pomoca, z okazji, z powodu, $z$ racji, z ramienia, $z$ tytulu, $z$ wyjatkiem.

Z pozostałymi przypadkami łączą się pojedyncze, izolowane przyimki wtórne. Rekcję celownikową mają prepozycje dzięki, na przekór, przeciw(ko), wbrew. $\mathrm{Z}$ biernikiem łączą się jedynie cztery przyimki wtórne, tj.: bez względu na, ze względu na, w zamian za, z uwagi na, natomiast z narzędnikiem trzy prepozycje: w porównaniu $z, w$ związu $z$, zgodnie $z$. Z miejscownikiem łączą się wyłącznie przyimki pierwotne $w, n a, p r z y, p o, o$. Mimo ich znikomej liczby locativus jest jedynym przypadkiem we współczesnym polskim systemie kazualnym wymagającym obligatoryjnie użycia przyimka. Syntetyczne formy miejscownikowe typu być lesie 'być w lesie' występowały w języku staropolskim.

$\mathrm{W}$ omawianym zakresie można wyróżnić cztery zasadnicze różnice, wynikające z odrębności typologicznej obu języków:

1. w polszczyźnie omawiane struktury są realizowane prepozycyjnie, w węgierszczyźnie natomiast zgodnie z zasadami aglutynacji postpozycyjnie;

2. wszystkie polskie przyimki wtórne - w przeciwieństwie do poimków węgierskich - łączą się wyłącznie z przypadkami zależnymi;

3. wszystkie rzeczowniki węgierskie mogą przybierać morfemy dzierżawcze;

4. część poimków węgierskich może przybierać morfemy dzierżawcze. 
Mimo wskazanych różnic system polskiego przyimka nie powinien przysparzać trudności Węgrom uczącym się języka polskiego. Problematyczne wydają się końcówki równoległe, zwłaszcza niewyjaśnione definitywnie użycie końcówek $-a \mathrm{i}-u$ w dopełniaczu liczby pojedynczej rodzaju męskiego, tj. przypadku o najwyższej frekwencji. Warto dodać, że istnieje wiele leksemów typu chaber, adapter, bestseller, neseser, rewolwer, folder, chałat, gdzie dobór odpowiedniej końcówki jest problematyczny dla rodowitych użytkowników języka. Innym kłopotliwym przypadkiem jest biernik rodzaju męskiego, gdzie w grupie rzeczowników nieżywotnych od kilku stuleci szerzy się męskożywotna końcówka - $a$. Czy Węgrzy uczący się języka polskiego powinni kupować arbuz, pomidor, ogórek, banan, seler - jak wskazuje norma wzorcowa - czy może arbuza, pomidora, ogórka, banana, selera, na co zezwala norma użytkowa? Należy tu podkreślić, że tego typu rzeczowników jest w polszczyźnie ponad tysiąc, a więc w żadnym wypadku nie można marginalizować ważkości problemu.

Na zakończenie warto podkreślić, że mimo odrębności genetycznej i typologicznej istnieje bardzo wysoki stopień ekwiwalencji w strukturach obu języków, zarówno w systemie leksykalnym, jak i gramatycznym, co jest dobrą przesłanką dla wszystkich zainteresowanych ich poznawaniem. Jednakże zrozumienie tak dalece odmiennych systemów językowych i ich praktyczne opanowanie jest poważnym wyzwaniem dla uczących się.

\section{BIBLIOGRAFIA}

Bajerowa I., 1964, Kształtowanie się polskiego języka literackiego w XVIII wieku, Wrocław.

Balogh J., 2000, A névutó, w: B. Keszler (red.), Magyar grammatika, Budapest, s. 261-265.

Balogh J., 2000, A névszóragozás, w: B. Keszler (red.), Magyar grammatika, Budapest, s. 183-208.

Csapláros I., 1963, Zarys elementarnej gramatyki węgierskiej, Warszawa-Łódź.

Elert T., 1995, Eesti grammatika, Tallinn.

Keszler B., 2000, A határozószó, w: B. Keszler (red.), Magyar grammatika, Budapest, s. 209-222.

Krążyńska Z., 2015, Staropolskie konstrukcje z przyimkami. Krótka synteza, „LingVaria”, nr 20, s. 193-204. https://doi.org/10.12797/LV.20.2015.20.15

Milewska B., 2003, Przyimki pierwotne we współczesnej polszczyźnie, Gdańsk.

Miodunka W., 1992, Język polski jako obcy. Programy nauczania na tle współczesnej polszczyzny, Kraków.

Polański K., 1993, Aglutynacja, w: K. Polański (red.), Encyklopedia językoznawstwa ogólnego, Wrocław.

Przybylska R., 2002, Polisemia przyimków polskich w świetle semantyki kognitywnej, Kraków.

Stefańczyk W., 2018, Polskie przyimki pierwotne a przypadki analityczne $w$ wegierskiej perspektywie porównawczej, „Acta Universitatis Lodziensis. Kształcenie Polonistyczne Cudzoziemców", t. 25, B. Grochala, I. Dembowska-Wosik (red.), s. 69-76. https://doi.org/10.18778/08606587.25 .06

Stopa R., Garlicki B, 1966, Mały stownik suahilijsko-polski i polsko-suahilijski, Warszawa.

Tokarski J., 2001, Fleksja polska, Warszawa. 
Velcsov M., 1991, A szófajok, w: J. Bencédy, P. Fábián, E. Rácz, M. Velcsov (red.), A mai magyar nyelv, Budapest, s. 11-56.

Wojan K., 2016, Język fiński w teorii i praktyce, Gdańsk.

Wiesław T. Stefańczyk

\title{
HUNGARIAN POSTPOSITIONS AND POLISH SECONDARY PREPOSITIONS - A COMPARATIVE APPROACH TO LANGUAGE TEACHING
}

Keywords: secondary preposition, postposition, Hungarian language, Polish language

\begin{abstract}
Hungarian is a prepositionless language. Polish, on the other hand, features two groups of prepositions: primary and secondary. The Hungarian equivalent of Polish primary prepositions is the synthetic case, e.g. Łódźban 'in Łódź', while the equivalent of secondary prepositions is the postposition, e.g. az anyámnak köszönheöen 'thanks to my mother', az egyetemmel szemben 'opposite of university'. There are three postposition groups in Hungarian language, including those connected with: Nominative case, e.g. a professzor szerint 'according to professor', oblique cases, e.g. az úton keresztül 'across the road' and those which contain possessive affix, e.g. az anyám dacára 'in spite of my mother'. Understanding and mastering both language systems poses a major challenge to learners. Despite genetic and typological variability, there is a very high degree of equivalence in the structures of both languages, both in lexical and grammatical systems.
\end{abstract}

Data wpłynięcia tekstu: 25.05.2020 